草

A High Reliability Oxygen Deficiency Monitoring System

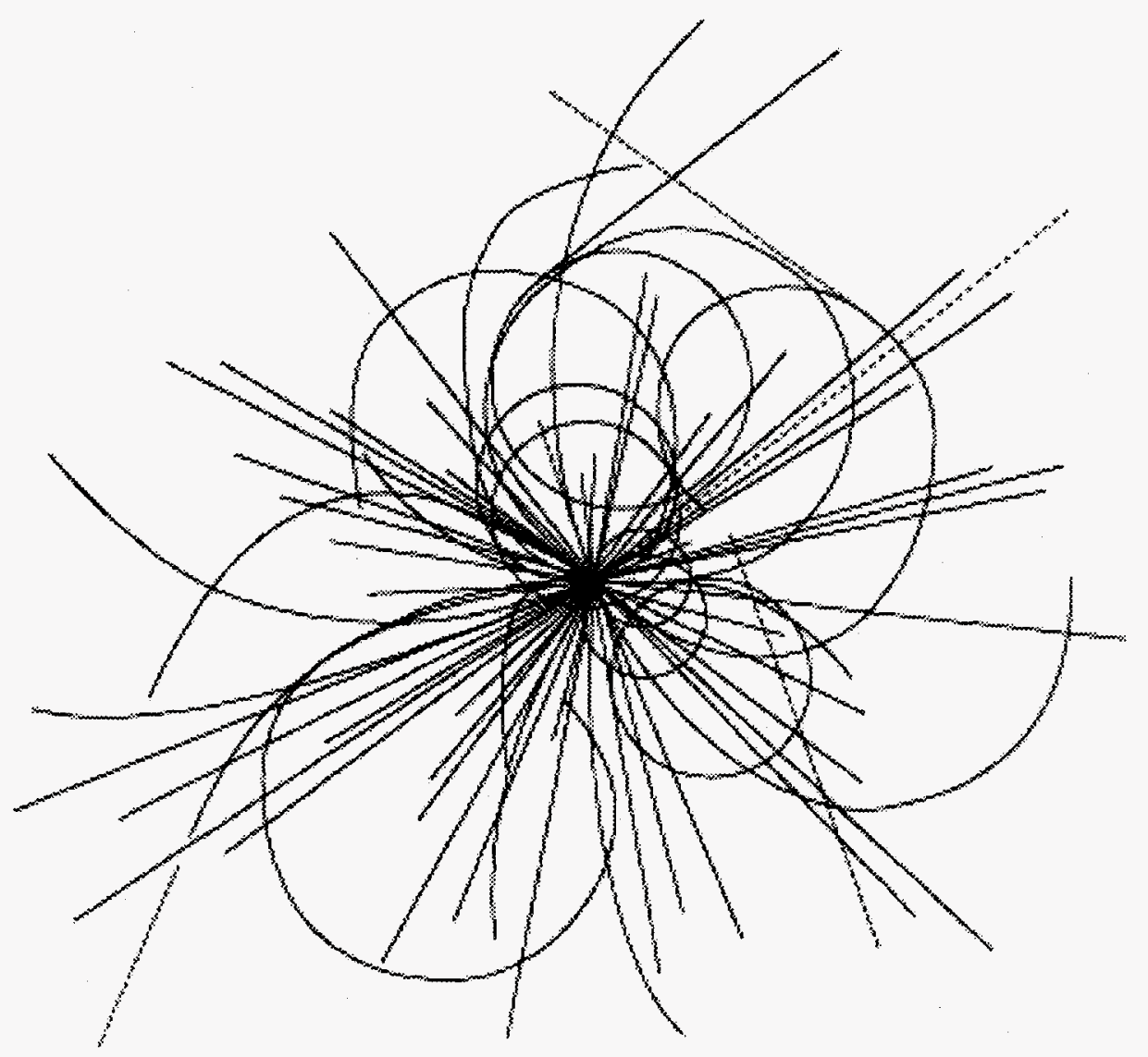

\section{Superconducting Super Collider Laboratory}

R. Parry

G. Claborn

A. Haas

R. Landis

W. Page

J. Smith 


\section{Disclaimer Notice}

This report was prepared as an account of work sponsored by an agency of the United States Govemment. Neither the United States Govemment or any agency thereot, nor any of their employees, makes any warranty, express or implied, or assumes any legal liability or responsibility for the accuracy, completeness, or usefulness of any information, apparatus, product, or process disclosed, or represents that its use would not infringe privately owned rights. Felerence herein to any specific commercial product, process, or service by trade name, trademark, manufactures, or otherwise, does not necessarily constitute or imply its endorsement, recommendation, or favoring by the United States Government or any agency thereot. The views and opinions of authors expressed herein do not necessarily state or reflect those of the United States Government or any agency thereot.

Superconducting Super Collider Laboratory is an equal opportunity employer. 


\section{DISCLAIMER}

Portions of this document may be illegible in electronic image products. Images are produced from the best available original document. 


\title{
A High Reliability Oxygen Deficiency Monitoring System*
}

\author{
R. Parry, G. Claborn, A. Haas, R. Landis, W. Page, and J. Smith \\ Superconducting Super Collider Laboratory ${ }^{\dagger}$ \\ 2550 Beckleymeade Ave. \\ Dallas, TX 75237
}

May 1993

*Presented at the 1993 IEEE Particle Accelerator Conference on May 17-20, Washington, D.C.

${ }^{+}$Operated by the Universities Research Association, Inc., for the U.S. Department of Energy under Contract No. DE-AC35-89ER40486. 


\title{
A High Reliability Oxygen Deficiency Monitoring System*
}

\author{
R. Parry, G. Claborn, A. Haas, R. Landis, W. Page, J. Smith \\ Superconducting Super Collider Laboratory \\ 2550 Beckleymeade Avenue, Dallas, TX 75237 USA
}

\section{Abstract}

The escalating use of cryogens at national laboratories in general and accelerators in particular, along with the increased emphasis placed on personnel safety, mandates the development and installation of oxygen monitoring systems to insure personnel safety in the event of a cryogenic leak. Numerous vendors offer oxygen deficiency monitoring systems but fail to provide important features and/or flexibility. This paper describes a unique oxygen monitoring system developed for the Magnet Test Laboratory (MTL) at the Superconducting Super Collider Laboratory (SSCL). Features include: high reliability, oxygen cell redundancy, sensor longevity, simple calibration, multiple trip points, offending sensor audio and visual indication, global alarms for building evacuation, local and remote analog readout, event and analog data logging, EMAIL event notification, phone line voice status system, and multi-drop communications network capability for reduced cable runs. Of particular importance is the distributed topology of the system which allows it to operate in a stand-alone configuration or to communicate with a host computer. This flexibility makes it ideal for small applications such as a small room containing a cryogenic dewar, as well as larger systems which monitor many offices and labs in several buildings.

\section{INTRODUCTION}

The Magnet Test Lab was constructed to perform acceptance and life tests on superconducting magnets. It is a complex of buildings and areas including: a compressor building, service building, main magnet test hall, control room, basement, and numerous lab areas and offices.

A release of cryogens (liquid helium and nitrogen) can create an oxygen deficiency hazard. If the release is sufficiently large, the loss causes displacement of oxygen in the area to less than life-supporting levels. The MTL oxygen monitoring system consists of: 21 oxygen sensors, 20 global audio/visual alarm units for personnel notification and evacuation, and 2 ventilation fan controllers. The sensors are placed where the highest probability exists for a leak such as valves and connecting joints. If both helium and nitrogen are present, oxygen sensors are placed in pairs. One sensor is located near the ceiling to detect oxygen deficiencies due to a liquid helium leak (helium is lighter than air and rises), the other is placed near the floor to detect deficiencies from a liquid nitrogen leak (cold nitrogen is slightly heavier than air and falls).

* Operated by the Universities Research Association, Inc. for the U.S. Department of Energy, under contract No. DEAC35-89ER40486

\section{OXYGEN SENSORS}

\section{A. Measuring Oxygen}

Several techniques may be used to measure oxygen. High accuracy methods are expensive, especially if a large number of sensors are to be used in applications like the MTL where many sensors are installed to provide adequate coverage. Inexpensive electrochemical oxygen cells are a better choice to detect oxygen deficiencies in these applications. These cells act like an oxygen sensitive battery, the more oxygen the cell is exposed to, the higher the voltage output from the cell. Conversely, less oxygen yields a lower voltage.

Note that the term cell as used in this paper refers to the small electrochemical device that is used for sensing oxygen content. The term sensor is used to indicate the $9^{\prime \prime} \times 9^{\prime \prime}$ unit containing cells, electronics, horn, and strobe.

\section{B. High Reliability}

For highest reliability the longevity of the sensor represents the greatest concern. Like a conventional battery, electrochemical oxygen cells have a finite life, typically 9 to 24 months. Experience has shown that the health of the cell is a major factor contributing to false alarms. Ailments range from infant mortality, to anomalous cell variations and ultimately to cell death. At first glance, using two cells would appear to be a solution. For example, if one cell drops below the safe level, we could switch to the other cell (one out of 2 voting). However, this is not a safe solution since an oxygen deficiency measured by one cell would not allow us to ascertain with certainty if the measured value is caused by an actual oxygen deficiency or a false alarm. The solution is to use three cells. Using a 2 out or 3 voting scheme allows one to differentiate between an actual oxygen deficiency and a single cell failure. Only if two cells agree does the system initiate an actual alarm. A single low reading sensor is voted out. In this way, false alarms are significantly reduced.

3 oo 3: Three cells are normal, select lowest value.

\begin{tabular}{llllll} 
Cell A & Cell B & Cell C & Result & Example & Result \\
\hline Norm & Norm & Norm & Norm & $20,21,22$ & 20
\end{tabular}

2 oo 3: Two cells are normal, select lowest value.

\begin{tabular}{llllll} 
Cell A & Cell B & Cell C & Result & Example & Result \\
\hline Norm & Norm & High & Norm & $20,22,25$ & 20 \\
Norm & Norm & Warn & Norm & $20,22,19$ & 20 \\
Norm & Norm & Alarm & Norm & $20,22,15$ & 20
\end{tabular}

1 oo 3: One cell is normal.

\begin{tabular}{llllll} 
Cell A & Cell B & Cell C & Result & Example & Result \\
\hline Norm & High & High & High & $20,24,25$ & 25 \\
Norm & High & Warn & Warn & $20,25,19$ & 19 \\
Norm & High & Alarm & Alarm & $20,25,15$ & 15 \\
0 oo 3: & \multicolumn{2}{l}{ No cells normal. } & & & \\
Cell A & Cell B & Cell C & Result & Example & Result \\
High & High & High & High & $24,25,26$ & 26 \\
High & High & Warn & Warn & $24,25,19$ & 19 \\
High & High & Alarm & Alarm & $24,25,15$ & 15
\end{tabular}


The preceding table lists the 2 out of 3 voting logic integrated into the software of the controller. The basic voting rule is to error on the side of safety, specifically this means select the case would result in a state equal to or more severe that the suspected state. For example, an alarm state is a safer state than the warning state since it causes additional actions such as activating the ventilation fans.

The triplication also carries with it fault tolerance and ease of maintenance. Should a cell fail during a running period, the cell need not be replaced immediately. Two of the three cells remain functioning to provide safe oxygen monitoring. However should another cell fail, an alarm will be initiated. The system provides a remote alarm indication which signifies the failure of the cell. During a maintenance period, the failed cell may be replaced without interrupting operations. Another benefit of triplication is added cell longevity. While the actual life of the cell is not lengthened, a normal maintenance program that replaces cells before they fail (i.e., replace cells as they approach their life expectancy) need not be implemented. Cells may remain in use until they actually fail.

Other factors affecting cell reliability are temperature, barometric pressure, and humidity. To assure high reliability each of these factors should be addressed. Temperature is a major contributor to inaccuracy and poor reliability. It is compensated for within the cell by a temperature compensating resistor. Although humidity also affects oxygen measurements, compensation need not be introduced since high accuracy is not required for personnel oxygen measurements. Barometric pressure does significantly affect cell accuracy. At this writing pressure compensation is not provided, however as shown in Figure 1, a pressure transducer is included for a possible future version.

\section{Set points}

The normal partial pressure of oxygen at sea level is 158 $\mathrm{mm} \mathrm{Hg}(158 / 760 \mathrm{~mm} \mathrm{Hg}=20.8 \%)$. Deleterious effects due to a lack of oxygen do not occur in healthy individuals until the partial pressure is less than approximately $135 \mathrm{~mm} \mathrm{Hg}$ $(17.8 \%)$. To insure that a warning is provided before this level is reached, $19.5 \%$ is defined as a safe level to indicate a possible hazard.

Based on this standard, several system states have been identified: normal, warning, alarm, and malfunction. The normal state is represented by oxygen levels between $19.5 \%$ and $23 \%$. A warning exists anytime the oxygen level is less than $19.5 \%$ and greater than $18.0 \%$. Personnel are notified of a warning by a intermittent horn. When the level falls below $18 \%$ an alarm state exists in which area horns, strobes, and ventilation fans are activated. The fans bring fresh air into the area. Measurements less than $0 \%$ or greater than $23 \%$ are considered system malfunctions since these measurements are considered erroneous in our application.

\section{Calibration}

The output of a typical electrochemical cell is $12 \mathrm{mv}$, but varies greatly between cells. Therefore the cells must be calibrated before installation and in the field if cells are replaced. Given the number of sensors and the precarious locations of many of the sensors, calibration must be simplified. The calibration method has been reduced to placing a "cup" connected to a calibrated reference gas $(20.8 \%)$ over the cells and depressing a "calibrate" switch. Software within the controller makes specific checks and normalizes the sensor's output to $20.8 \%$.

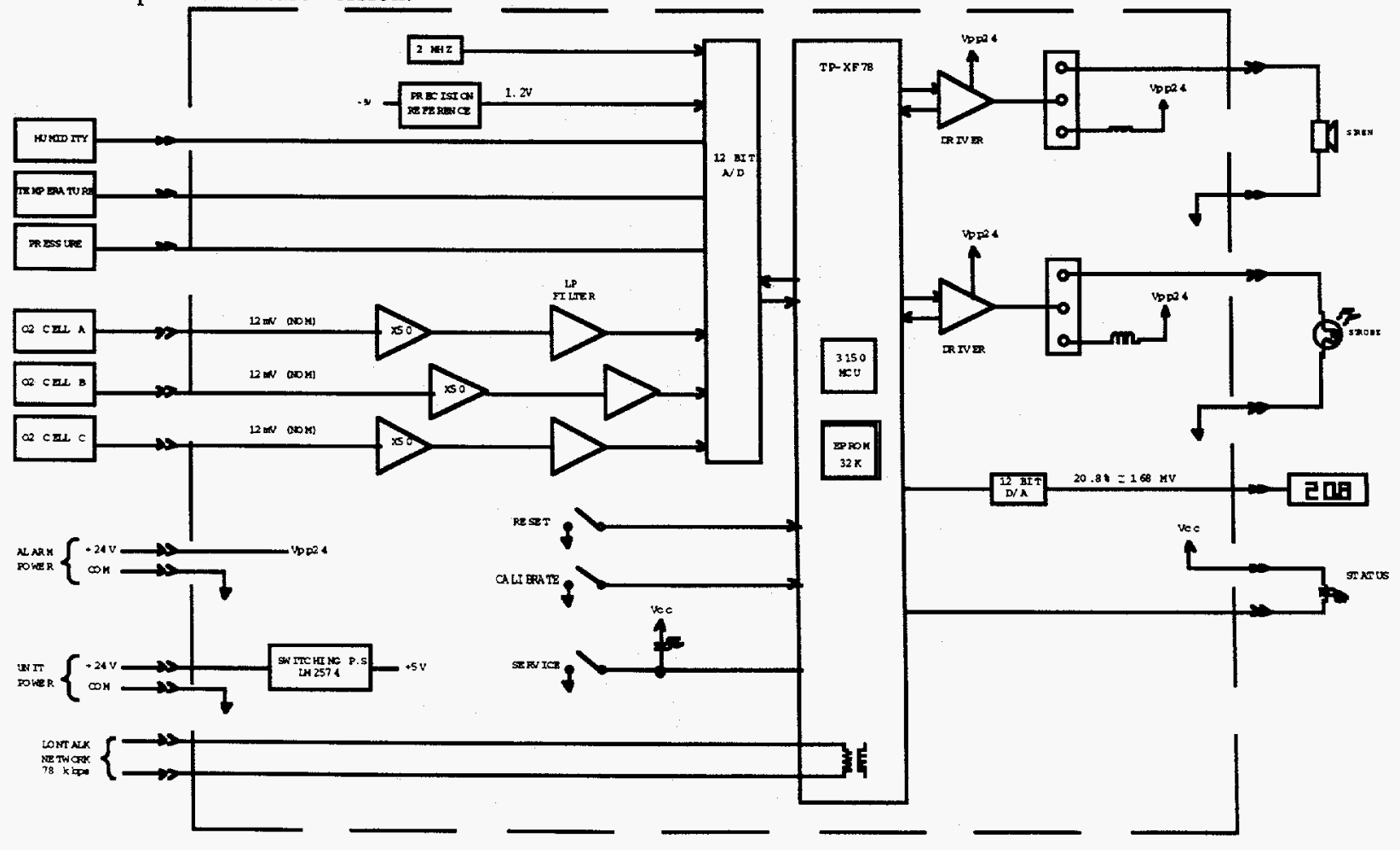

Figure 1. Block diagram of the oxygen monitor. The heart of the system is the Echelon 3150 Neuron Chip. The three oxygen cells are shown as A, B, and C. The humidity, temperature, and pressure transducer are not implemented in the present design. The unit is powered by a single $24 \mathrm{vdc}$ supply. Alarm power for the horn and strobe is separate. 


\section{THE NETWORK}

\section{A. Features}

Providing notification to personnel of a hazardous condition is of paramount importance. For this reason both visual and audible indications in the form of strobe lights and evacuation horns are provided. Additional alarms attached directly to the sensors indicate locally the status of the oxygen sensors and aid in locating the offending unit.

The analog level is digitally displayed on the front of the unit. This value may also be ascertained remotely via the operator interface console. The analog levels are also recorded at 15 second intervals. These data files are kept for 7 days which provides adequate historical records for purposes of analysis and fault reconstruction. Plotting software is available for easy and concise display of the data. Discrete state changes such as warning, alarm, and normal are time and date stamped and logged. This information proves valuable in ascertaining system reliability.

For non-operating periods of the MTL, remote notification of alarming events is provided in two forms. By way of the lab wide Ethernet network, EMAIL messages are broadcast to maintenance personnel. A dedicated VMAIL (Voice Mail) system initiates telephone calls to phones and/or pagers. This system also allows for call-in status requests from a remote location to ascertain oxygen levels of oxygen sensors.

\section{B. Hardware}

The need to provide adequate coverage requires many sensors in often precarious and/or remote locations. Some are suspended from a $30^{\prime}$ high ceiling and others in pits or basements. Running cable and conduit to these locations represents a significant cost. The need to reduce cable complexity was answered by a new communication technology developed by Echelon $($ Corporation and embodied in the 3120 and 3150 Neuron integrated circuits manufactured by Motorola ${ }^{\circledR}$ and Toshiba $\otimes$. A "multi-drop" network topology is used which allows for sensor communication over a single twisted pair cable. This has the advantage of also reducing conduit size and therefore further reducing installation costs. For our application $78 \mathrm{Kbps}$ was used (1.25 Mbps is also available). Other communications media are available such as RF (4800 bps), power line ( $9600 \mathrm{bps})$, coax, IR, and optical fiber.

The Neuron is basically a standard microcontroller such as the Motorola 68HC11 and Intel 8051 with internal RAM, ROM, and EEPROM. What makes this chip unique is the powerful built-in communications capability, LonTalk ${ }^{\mathrm{TM}}$, a proprietary seven-layer network protocol. Peer to peer communications is easy to implement allowing any sensor to broadcast messages to any other sensor or for that matter any device on the network. Error checking, packet assembly, acknowledgment and retries are implemented within the Neuron and are transparent to the programmer. A predictive Carrier Sense Multiple Access (CSMA) with optional collision detection is used for communications and provides high throughput even at high traffic rates. Transformer coupling provides additional fault tolerance to cell failures which may otherwise adversely affect the network.

\section{Software}

Software is required to implement the many features described. The software is written in Neuron $C$ which contains several extensions to standard $C$ which allows the programmer to easily take advantage of the Neuron's features. Neurons communicate with each other by the use of input and output network variables. In our application, the fan controllers and alarm units have input variables and the oxygen monitors, output variables. In order for a cell to control a fan, a connection between the nodes must be made. This process is called, "binding". Therefore the logic (program) that might normally be implemented in a single controller, is implemented in a database of bindings.

\section{CONCLUSION}

Use of oxygen monitoring systems will continue to expand in use at national laboratories and represent a large subsystem at the SSCL. False alarms of such systems adversely affects humans and creates both operational and availability problems. Using triplicated cells provides increased reliability from several types of cell failures. In addition, the distributed control system described has great flexibility and saves on both cable and installation costs.

\section{BIBLIOGRAPHY}

[1] J. Butler, "Embedded Controller Networking Alternatives," Circuit Cellar INK, issue \#26, (April/May - 1992).

[2] K. Davidson, "Echelon's Local Operating Network," Circuit Cellar INK, issue \#21, (April/May - 1991).

[3] R. Parry, "Personnel Access Safety Systems at the Superconducing Super Collider," Proceedings of the Industrial Computing Conference, Vol 2, p. 437, ISA, 1992 - Paper \#92-0467.

[4] M. Zalenski, et. al, "Operational Considertions in Monitoring Oxygen Levels at the National Transonic Facility," NASA Contractor Report 3953, (December 1985).

[5] "LonBuilder ${ }^{\mathrm{TM}}$ User's Guide," Echelon $\circledast$ Corporation, Palo Alto, CA. USA.

[6] "Neuron $®$ C Programmer's Guide," Echelon ${ }^{\circledR}$ Corporation, Palo Alto, CA. USA. 